\title{
The Relationship between Orthodontic Treatment Need and Psychosocial Impact in University of Sumatera Utara Undergraduate Student
}

\author{
Aditya Rachmawati \\ Department of Orthodontic \\ Faculty of Dentistry, Universitas Sumatera Utara \\ Medan, Indonesia \\ aditya_rachmawati@yahoo.com
}

\author{
Erliera \\ Department of Orthodontic \\ Faculty of Dentistry, Universitas Sumatera Utara \\ Medan, Indonesia \\ erliera.triadi@gmail.com
}

\begin{abstract}
Teeth and mouth are a lifetime health investments for human. Various disease and anomaly of the teeth and mouth may impair the function of oral cavity; one of them is malocclusion, anomaly of the alignment of the teeth. Teeth in good position relative to the arch not only support the health of oral cavity, but also act as prerequisite for an attractive smile, ultimately improve the self-confidence and attractiveness of the individual. This research was done to evaluate the association between orthodontic treatment need and psychosocial status of the undergraduate students of University of Sumatera Utara (USU). The research was analytical in cross-sectional design. The result showed that the majority of samples were female $(n=74,37 \%)$, the largest number of samples was in medium psychosocial status (PIDAQ score 30.7-61.3) $(n=93,46.5 \%)$, and based on chi- square test, there was a significant association between orthodontic treatment need and psychosocial status of the students of USU $(p=0.000)$.
\end{abstract}

Keywords-orthodontics treatment need, psychosocial impact, IOTN-DHC, PIDAQ

\section{INTRODUCTION}

The appearance of the face, particularly eyes and mouth, constitutes the highest factor in shaping the esthetic perception of an individual [1]. Based on family health survey by Indonesian Health Department in 2004, amid all illnesses that were or were not complained, teeth and mouth disease held the highest prevalence of $60 \%$ population [2]. Various disease and anomaly of the teeth and mouth may impair the function of oral cavity; one of them is malocclusion, anomaly of the alignment of the teeth [3].

Malocclusion is a form of teeth occlusion that deviates from normal and accounts for a type of dentofacial anomaly of morphogenic origin [4]. Malocclusion is stated to be the second highest teeth problem in children and adolescence after caries [5]. The prevalence of malocclusion in adolescence in Indonesia is constantly high, from $90 \%$ in 1983 to $89 \%$ in 2006 [2].
Esthetics of the teeth affects social interaction and psychological wellbeing of an individual. The ensuing shame someone feels from abnormal teeth alignment can negatively affect the person's self-concept and social relationship. Malocclusion involving anterior teeth, such as large overjet, crowded teeth and spacing, often induce negative image and reaction towards the person, which sometimes go as far as limiting job opportunity, thus creating negative stereotype that degrades self-esteem [6].

Adolescence period is the stage of self-identity formation and in this stage facial and teeth esthetic hold significant role in the development of self-concept and self-pride. Unattractive facial appearance has unfavorable effect on adolescent psychological development. Depending on the severity, malocclusion may impair social interaction, psychological wellbeing, self-confidence, as well as pride on appearance [1].

Research by Munizeh and Fida in University Hospital of Karachi, Aga Khan in 2008 found that $14,6 \%$ samples showed dissatisfaction to the appearance of their teeth and acknowledged its impact on their self-esthetic [7]. De Paula- Junior et al in 2009 stated that adolescent would feel the impact on quality of life in association with the severity of malocclusion, where the higher the severity, the lower the quality of life $[8,9]$. In their research on the relationship between malocclusion and self-confidence in children aged 1218 year old in 2014, Sun and Jiang found that malocclusion can give negative impact on the adolescent's self-confidence [10].

With the high level of prevalence of malocclusion in Indonesia and the variety problems it can ensue, among which the psychosocial impact on the patient, and with the usage of fixed orthodontic appliance on the rise among young people, this article was done to investigate the association between the level of orthodontic treatment need and psychosocial status in the students of University of Sumatera Utara. 


\section{MATERIALS AND METHODS}

The research was analytical in cross-sectional design. Two hundred active students of University of Sumatera Utara formed the research population and the collection of samples was done in purposive sampling method. The inclusion criteria were: (1) no history of fixed orthodontic treatment, (2) patient is indicated to wear fixed orthodontic appliance and has malocclusion according to IOTN index (DHC) grade 1 , grade 2 , grade 3 , grade 4 and grade 5 . The research was commenced after gaining approval from the ethical committee of USU (Health Research Ethical Committee of North Sumatera).

The initial step in the research procedure was intraoral examination on sample candidate. If they fulfill the inclusion criteria, the upper and lower impressions were taken afterwards. Malocclusion analysis was done on the study model to classify the level of orthodontic need using Index of Orthodontic Treatment Need-Dental Health Component (IOTNDHC). IOTN-DHC is an index that objectively analyzed the malocclusion based on overjet, overbite, crossbite, and missing or shifting contact points. DHC only scores the worst feature of occlusion that affects teeth function and health in long term $[11,12]$. Orthodontic treatment need was classified into five grades, where grade 1 is condition that does not require treatment, grade 2 is condition which requires mild treatment, grade 3 is condition which requires borderline treatment, grade 4 requires treatment, and grade 5 is condition in serious need of treatment.

The samples filled the Psychosocial Impact of Dental Aesthetic Questionnaire (PIDAQ) that consists of 23 questions classified into four domains: dental selfconfidence, social impact, psychosocial impact, and aesthetic concern. To evaluate the psychosocial, psychological and esthetic impact, the scoring system was based on the subject's answer: $0=$ not at all; $1=\mathrm{a}$ little; $2=$ somewhat; $3=$ agree; and $4=$ strongly agree. To evaluate dental self-confidence, the scoring system was: $4=$ not at all; $3=a$ little; $2=$ somewhat; $1=$ agree; and $0=$ strongly agree. The overall score of all questions was calculated; with the minimum and maximum possible score is 0 to 92 . The result was classified as follows: $0-30.6$ = good level of psychosocial status; 30.7-61.3 = medium level of psychosocial status; and $61.4-92=$ low level of psychosocial status.

Chi square test was applied in data analysis to assess the association of orthodontic treatment need with psychosocial status was done with chi square test.

\section{RESULTS}

From 200 samples, the male samples were fewer than female, 53 males $(26.5 \%)$ vs. 147 females (73.5\%). Based on age, 69 samples were 18 years old (34.50\%), 64 samples were 19 years old (32\%). Fortythree samples were 20 years of age $(21.50 \%)$ while the smallest group of samples $(\mathrm{n}=24 ; 12 \%)$ was 21 years of age.

TABLE I. SAMPLE CHARACTERISTIC BASED ON SEX AND AGE (N=200)

\begin{tabular}{|l|c|c|}
\hline \multicolumn{1}{|c|}{ Characteristic } & n & \% \\
\hline Sex & & \\
Males & 53 & 26.50 \\
Females & 147 & 73.50 \\
Age (year) & 69 & \\
18 & 64 & 34.50 \\
19 & 43 & 32.00 \\
20 & 24 & 21.50 \\
21 & & 12.00 \\
\hline
\end{tabular}

The analysis of orthodontic treatment need revealed that most of the samples fell into grade 2 $(n=74 ; 37 \%)$, followed by grade $1(n=40 ; 20 \%)$, grade 4 $(\mathrm{n}=38 ; 19 \%)$, grade $3(\mathrm{n}=27 ; 13.5 \%)$ and finally grade 5 (21 samples; $10.5 \%$ ).

TABLE II. THE NEED OF ORTHODONTIC TREATMENT

\begin{tabular}{|l|l|l|}
\hline The need of orthodontic treatment & $\mathbf{n}$ & $\mathbf{\%}$ \\
\hline Grade 1 & 40 & 20.00 \\
Grade 2 & 74 & 37.00 \\
Grade 3 & 27 & 13.50 \\
Grade 4 & 38 & 19.00 \\
Grade 5 & 21 & 10.50 \\
\hline
\end{tabular}

It was shown that the average of samples had medium level of psychosocial status (PIDAQ score 30.7-61.3) namely $46.5 \%$; while the rest of samples fell between good (PIDAQ score $0-20.6$ ) of $28.5 \%$ and low level of psychosocial status (PIDAQ score 61.4-92) of $25 \%$.

TABLE III. PSYCHOSOCIAL STATUS

\begin{tabular}{|l|c|c|}
\hline \multicolumn{1}{|c|}{ Psychosocial status } & n & \% \\
\hline Good & 57 & 28.5 \\
Medium & 93 & 46.5 \\
Low & 50 & 25 \\
\hline
\end{tabular}

The analysis of the psychosocial status associated with orthodontic treatment need by chi square test showed that there was a significant relation between orthodontic treatment need and psychosocial status of the students of USU, with statistic value of $p=0.000$ $(\mathrm{p}<\alpha)$.

TABLE IV. THE ASSOCIATION BETWEEN ORTHODONTIC TREATMENT NEED AND PSYCHOSOCIAL STATUS

\begin{tabular}{|l|c|c|c|c|c|}
\hline $\begin{array}{c}\text { The need of } \\
\text { orthodontic } \\
\text { treatment }\end{array}$ & \multicolumn{3}{|c|}{ Psychosocial status } & \multirow{2}{*}{ n } & \multirow{2}{*}{ p } \\
\cline { 2 - 5 } & Good & Medium & Bad & & \\
\hline Grade 1 & 40 & 0 & 0 & 40 & \\
Grade 2 & 17 & 57 & 0 & 74 & \\
Grade 3 & 0 & 27 & 0 & 27 & 0.000 \\
Grade 4 & 0 & 9 & 29 & 38 & \\
Grade 5 & 0 & 0 & 21 & 21 & \\
\hline
\end{tabular}

\section{DISCUSSION}

The objective evaluation of orthodontic treatment need based on Dental Health Component Index showed that the $37 \%$ students of USU required mild orthodontic treatment (Grade 2), predominantly female in age group 
18-19 years. This result was supported by Johal et al in their research in 2007 about the impact of malocclusion to the quality of life, which stated that perception of teeth and facial appearance was influenced by a variety of factors, including sex, social economic background and age [13]. Females tend to have higher attention and greater awareness of teeth appearance than males, and adolescent period was deemed as important period for the individual to begin social interaction in where physical appearance held the utmost significance to attract the opposite sex [14,1]. It is imperative for the teenagers and adolescents to immediately attend the malocclusion problem that might negatively influence their facial appearance so as to improve their quality of life $[15,16]$.

The assessment of psychosocial status is an evaluation of a patient that takes into account not only the physical health, but also the patient's perception of self and the desire to improve [17]. The research on the students of USU showed that $46.5 \%$ of the samples had medium level of psychosocial status (PIDAQ score 30.7-61.3). This result was in agreement with the research conducted by De Paula-Junior et al. on 301 teenagers in group age 13-20 years, in which they found that although the dissatisfaction with dental appearance is broadly related to the severity of irregularities, it is not uncommon to observe that some patients with severe malocclusions are satisfied with or indifferent to their dental esthetics and does not hinder their social activities [8].

The severity of malocclusion greatly influences the need of orthodontic treatment, as well as the level of satisfaction to life and pride, and psychosocial aspect in the individual $[15,16]$. This research on the association of orthodontic treatment need and psychosocial status on the students of USU revealed that there is significant relationship between those two variables. This concurred with another researches, such as Sun and Jiang's investigation on the relationship between malocclusion and self-confidence in 12-18 year olds, which reported that malocclusion may negatively impact the adolescent's self-confidence [10]. Munizeh and Fida in Aga Khan University Hospital of Karachi also found that $14.6 \%$ dissatisfaction level to dental appearance and it may influence the individual's perception of self-esthetic [7].

Individual with unattractive facial form due to malocclusion might endure detrimental psychological experience, hence increasing orthodontic treatment need, but the main principle of social psychology is that although individual characteristic influence the person to do something, social situation is a stronger determinant of behavior than personality. Human tend to feel comfortable with their own selves if they have adequate social interaction and they are accepted and cared by another person. If the need of social acceptance is not fulfilled, the individual might have low self-esteem $[1,18,19]$.

\section{ACKNOWLEDGMENT}

The author would like to express appreciation to University of Sumatera Utara for providing the fund for this research.

\section{REFERENCES}

[1] D.C. Sambeta, P.S. Anindita, Juliatri, "Pengaruh maloklusi gigi anterior terhadap status psikososial pada siswa SMA Negeri 1 Luwuk," Jurnal e-Gigi, vol. 4(1), pp. 59-63, 2016.

[2] O. Dewi, Analisa hubungan maloklusi dengan kualitas hidup pada remaja SMU Kota Medan tahun 2007, Tesis, Program S2 Kedokteran Gigi Universitas Sumatera Utara, Medan, 2008.

[3] X. Flores, R. Benavides, J. Berrera J, et al., "Prevalence of caries, gingivitis and malocclusions in school-agechildren in Ciudad Victoria, Tamaulipas, and its relationship with their nutritional status," Revista Odontológica Mexicana, vol. 17(4), pp. 217-223, 2013

[4] S. Premkumar, Prep manual for undergraduates: Orthodontics, New Delhi: Elsevier, 2008.

[5] S. Suma, C. Shekar, B. Manjunath, "Assessment of malocclusion status in relation to area of residence among 15 year old school children using Dental Aesthetic Index," Int. J. Dental Clinics, vol. 3(2), pp. 14-17, 2011.

[6] R.Y. Arsie, Dampak berbagai karakteristik oklusi gigi anterior terhadap status psikososial remaja awal, Tesis. Program S2 Universitas Indonesia. Jakarta, 2012.

[7] M. Khan, M. Fida, "Assesment of psychosocial impact of dental aesthetic," Journal of The College of Physicians and Surgeons Pakistan, vol. 18 (9), pp. 559-564, 2008.

[8] D.F. De Paula Junior, N.C.M. da Santos, E.T. Silva, M.F. Nunes, C.R. Leles, "Psychosocial impact of dental aesthetics on quality of life in adolescents," Angle Orthod., vol. 79, pp. 1188 1193, 2009.

[9] D. Ekuni, M. Furuta, K. Irie, T. Azuma, T. Tomofuju, T. Murakami, et al., "Relationship between impacts attributed to maloclusion and psychological stress in young Japanese adults," Eur. J. Orthod., vol. 33, pp. 558-563, 2011.

[10] A. Sheikh, T. Mathew, T.B. Siew, "Dental malocclusion among university students and its effect on self-esteem: A crosssectional study," World J of Dentistry, vol. 5, pp. 204-208, 2014.

[11] M. Flores, P.W. Major, F.R. Salazar, "Self-perceived orthodontic treatment need evaluated through 3 scales in a university population," Journal of orthodontic scientific section, vol. 3, pp. 329-334, 2004.

[12] J.H. Langlois, L. Kalakanis, A.J. Rubenstein, A. Larson, M. Hallam, M. Smoot, "Maxims or myths of beauty? A metaanalytic and theoretical review," Psychol. Bull., vol. 126(3), pp. 390-423, 2000

[13] A. Johal, M.Y.H. Cheung, W. Marcenes, "The impact of two different malocclusion traits on quality of life," British Dent. J., vol. 33, pp. 1-4, 2007.

[14] Devya. "Hubungan citra diri dan perilaku konsumtif pada remaja putri yang memakai kosmetik wajah," eJournal Psikologi, vol. 3, pp. 433-40, 2015.

[15] P. Arrow, D. Brennan, A.J. Spencer. "Quality of life and psychosocial outcomes after fixed orthodontic treatment: a 17year observational cohort study," Community Dentistry and Oral Epidemiology, vol. 39, pp. 511-514, 2011

[16] T.G. Rappaport, M.R. Shalis, E. Gazit. "Psychosocial reward of orthodontic treatment in adult patients," Eur. J. Orthod., vol. 32: 444-446, 2010.

[17] H.A. Kiyak, "Patients and parents expectations from early treatment," Am. J. Orthod. Dentofacial. Orthop., vol. 129, pp. 50-54, 2006.

[18] Saylor. (2017, February 4) Principles of sociological inquiryqualitative and quantitativa methods. Available: http://www.saylor.org/books.

[19] J.W. Santrock, Adolescence, $6^{\text {th }}$ ed., Adelar SB (translator). Jakarta: Penerbit Erlangga, 2003, pp. 228-338. 